
\title{
3 Research Square \\ Early plant defense-related responses triggered by a novel glycoprotein from Streptomycin
}

\section{Lirong Han}

Northwest Agriculture and Forestry University

Yubo Sun

Northwest Agriculture and Forestry University

Xin Zhou

Northwest Agriculture and Forestry University

xinchang Hao

Northwest Agriculture and Forestry University

Meng Wu

Northwest Agriculture and Forestry University

Xing Zhang

Northwest Agriculture and Forestry University

Juntao Feng ( $\sim$ fengjt@nwafu.edu.cn )

Northwest Agriculture and Forestry University https://orcid.org/0000-0002-5320-1178

\section{Research article}

Keywords: Glycoprotein, Streptomyces sp., plant defense response, PAMPs, SA and JA

Posted Date: July 9th, 2019

DOI: https://doi.org/10.21203/rs.2.11105/v1

License: (c) (i) This work is licensed under a Creative Commons Attribution 4.0 International License.

Read Full License 


\section{Abstract}

Background A novel glycoprotein from Streptomyces sp. ZX01, GP-1, has high activity against tobacco mosaic virus (TMV). With small molecular weight and water-soluble characteristics, GP-1 has tremendous commercial value. Though previous study indicated a plant immunity-inducing effect, the antiviral mechanism of GP-1 is still unclear. Results In this study, early plant defense-related responses, such as $\mathrm{Ca} 2+$ transient peak, callose apposition, oxidative burst, hypersensitive response (HR), programmed cell death (PCD), NO rising and stomatal closure, were thoroughly investigated and we studied the mechanism of how GP-1 can induce virus resistance in Nicotiana benthamiana in additional detail. Results showed that GP-1 could induce [Ca2+]cyt rapidly both in tobacco leaves and suspension cells, followed by ROS and NO elevation. Similar with typical pathogen-associated molecular patterns (PAMPs), GP-1 induces callose deposition and stomatal closure to form defense barriers for pathogen invasion. The expression of defense-related genes further supported these phenomena. The gene with CAM5 was obtained by RNA sequencing in Nicotiana benthamiana. Conclusions Through analyses of expression of SA, JA and CAM5, it was shown that GP-1 enhanced the virus resistance of tobacco by improving expression of CAM5 and the SA and JA content.

\section{Background}

Tobacco mosaic virus (TMV), a notorious plant pathogen, has a wide host range of over 885 plant species in 65 families, and causes serious economic losses worldwide (Yonghui Ge, et al., 2012). Besides the practical benefits related to controlling TMV and treating infected commercial hosts, TMV represents a paradigm in virology and represents a very difficult challenge for the researcher. Though conventional techniques of eradication from the soil have been tested over the last century, few virus-curative agrochemicals are available in the market (Andrea, L., et al., 2017). Induction of plant resistance, either achieved by chemicals (systemic acquired resistance, SAR) or by rhizobacteria (induced systemic resistance, ISR) is a possible and/or complementary alternative to manage virus infections in crops (Faoro, F., \& Gozzo, F., 2015).

Some artificially synthesized chemicals and natural chemicals or proteins have been shown to have SAR inducing effects. The antiviral agent ningnanmycin (NNM) lead to curative rates of 30-60\% (Ouyang, G., et al., 2008), however, the results mainly refer to lab tests and more data on open-field applications are needed (Andrea, L., et al.,2017). BTH (trademarks: Bion ${ }^{\mathrm{TM}}$ in Europe, Actigard ${ }^{\mathrm{TM}}$ in USA), is a functional analogue of salicylate. It was the first commercial product to induce an artificial type of SAR against systemic virus infection, e.g. TMV in tobacco Xanthi "nn" (Friedrich, L., et al., 1996).

Microbial elicitors of plant defence are active small molecules produced during the interaction between a pathogen and its host, and include oligosaccharides, glycoproteins, glycopeptides, proteins, polypeptides, lipids, and other cellular metabolites. These inducers are recognized by pattern-recognition receptors (PRRs) on the surfaces of plant cells and trigger plant defense responses, resulting in systemic resistance (Dewen, Q. et al.,2017). Chitosans are natural, non-toxic and inexpensive products obtained by 
deacetylation of chitin from the exoskeleton of crustacean and other arthropods. The capacity of inducing resistance against viral diseases, such as bean common mosaic virus (BCMV), bean yellow mosaic virus (BYMV), alfalfa mosaic virus (AMV), peanut stunt virus (PSV) and TMV, by chitosans is long known. Unfortunately, the use of chitosans in crop protection is still hampered by some limitations, such as unstable activity and water insolubility (Faoro, F., \& Gozzo, F., 2015). Plant growth promoting rhizobacteria (PGPR), as well as photoprotein-induced systemic resistance, is the other two worthwhile strategies that could be developed to curb virus infection and spread (Prasad, V., et al., 2014).

Additionally, Jacalin-type lectin, RTM1 (RESTRICTED TEV MOVEMENT 1) from Arabidopsis, two other lectin-like proteins isolated from Cyamopsis tetragonoloba and Dioicin 2, a typical ribosome inactivating protein (RIP) from Phytolacca dioica, showed strong antiviral activity. However, the type of resistance they induced does not depend on HR or SAR signaling, and the molecular weights of these proteins hindered the industrial production (Faoro, F., \& Gozzo, F., 2015).

GP-1, a glycoprotein from Streptomyces sp. ZX01 with high activity against TMV, was previously isolated in our lab, which has a small molecular weight of $8479 \mathrm{Da}$ and a water-solubility easing its production (Zhang, G., et al., 2015). The protective efficacy (87.58\%) of GP-1 was significantly higher than the curative efficacy $(13.44 \%$ ) on Nicotiana tabacum indicating a plant immunity-inducing effect. Further experiments proved that GP- 1 induced the SAR, in the form of increasing of superoxide dismutase (SOD), polyphenol oxidase (PPO) and phenylalanine ammonia lyase (PAL) activity, decreasing of malondialdehyde (MDA) content and strongly expressing of pathogenesis-related proteins (PRs) in tobacco plant (Zhang, G., et al., 2016). The anti-virus mechanism of polysaccharides, chitosan as an example, has been thoroughly studied, which involves $\mathrm{Ca}^{2+}$ transient peak, callose apposition, oxidative burst, hypersensitive response (HR), programmed cell death (PCD), NO rising and stomatal closure (Srivastava, N., et al., 2009; Wang, W., et al., 2008). However, limited information can be found for glycoproteins. In this study, the early plant defense responses were examined using GP-1 to elucidate the immunity-inducing mechanism of glycoproteins.

\section{Results}

HR and PCD induced by GP-1

The induction of necrosis by GP-1 was determined by observing the development of a necrotic spot at the site of injection of $50 \mu \mathrm{l}$ of GP-1 $(100 \mu \mathrm{g} / \mathrm{mL})$ into tobacco leaves. A transparent spot was visible in the infiltrated area at $4-8 \mathrm{~h}$ after inoculation, and the necrotic lesion became obvious at $12-24 \mathrm{~h}$ posttreatment (Fig. 1a). Evans blue staining showed an obvious cell death after GP-1 treatment (Fig. 1b). Serial dilution of the elicitor showed that GP-1 induced PCD at a concentration as low as $50 \mu \mathrm{g} / \mathrm{mL}$. Additionally, GP-1 can quickly induce PCD in a time- and concentration-dependent manner (Fig. 1C). Altogether, GP-1 may activated receptors on the plasma membrane and induced HR and PCD.

Induction of ROS production 
Hydrogen peroxide polymerized by 3, 3'-diaminobenzidine (DAB), which forms a dark red-brown precipitate, was detected, and the sites of $\mathrm{H}_{2} \mathrm{O}_{2}$ accumulation. A strong signal was obviously observed microscopically in tobacco leaves after $2 \mathrm{~h}$ after treatment with GP-1 (100 $\mu \mathrm{g} / \mathrm{mL})$ (Fig. 2a). ROS production induced by GP-1 was also visualized through DCFH-DA in tobacco suspension cells (Fig. 2b). The quantification of $\mathrm{H}_{2} \mathrm{O}_{2}$ in tobacco leaves and cell suspension and compared to a negative control was further conducted. GP-1 treatment caused a rapid increase in $\mathrm{H}_{2} \mathrm{O}_{2}$ in leaves, which reached a maximum at about $3 \mathrm{~min}$, followed by a gradual decrease to a level similar to that of the negative control in 10 minutes (Fig. 2c). Similar phenomenon of $\mathrm{H}_{2} \mathrm{O}_{2}$ production was observed for tobacco suspension cells, with the peak of $\mathrm{H}_{2} \mathrm{O}_{2}$ production appearing 30 min after GP-1 treatment (Fig. 2d).

Effects of GP-1 on $\left[\mathrm{Ca}^{2+}\right]_{\mathrm{cyt}}$ elevation

It was observed that, the resting $\left[\mathrm{Ca}^{2+}\right]_{\mathrm{cyt}}$ was not changing in control cells. GP-1 treatment in tobacco cells induced an elevation of $\left[\mathrm{Ca}^{2+}\right]_{\mathrm{cyt}}$ at about $10 \mathrm{~s}$. $\left[\mathrm{Ca}^{2+}\right]_{\mathrm{cyt}}$ peak was observed after about $200 \mathrm{~s}$ and a periodic increase was observed 200s-1200s later (Fig. 3). The addition of $\mathrm{Ca}^{2+}$ chelator EGTA suppressed the $\left[\mathrm{Ca}^{2+}\right]_{\mathrm{cyt}}$ increase induced by GP-1, indicating that $\left[\mathrm{Ca}^{2+}\right]_{\mathrm{cyt}}$ elevations depended on the $\mathrm{Ca}^{2+}$ influx from the extracellular medium. These data provided evidence for the involvement of $\mathrm{Ca}^{2+}$ in the GP-1 mediated signaling.

Elevation of NO levels and stomatal closure induced by GP-1

GP-1 induces the appearance of cells showing bright fluorescence due to NO accumulation (Fig. 4a) and NO production showed a dose-dependent manner (Fig. 4b). Application of $100 \mu \mathrm{g} / \mathrm{mL} \mathrm{GP-1}$ resulted a rapid increase of NO in both tobacco suspension cells (Fig. 4c) and leaves (Fig. 4d).

As GP-1 may induce the accumulation of NO, it may also have a role in stomatal closure. In this study, GP-1 could induce stomatal closure in tobacco, as is the case with ABA. The effect of GP-1 on promotion of stomatal closure was significant $(P<0.05)$ at concentrations above $50 \mu \mathrm{g} / \mathrm{mL}$. Application of 50 $\mu \mathrm{g} / \mathrm{mL}, 100 \mu \mathrm{g} / \mathrm{mL}, 200 \mu \mathrm{g} / \mathrm{mL}$ GP-1 reduced stomatal apertures by $23.3 \%, 38.9 \%$, and $49.6 \%$, respectively, and showed a does-dependent manner (Fig. 5). Maximum stomatal closure occurred at 200 $\mu \mathrm{g} / \mathrm{mL}$, under which conditions the stomatal apertures were $2.31 \pm 0.19 \mu \mathrm{m}$, or $50.4 \%$ of the control value (5.01 $\pm 0.14 \mu \mathrm{m})$ (Fig. 5).

Callose production induced by GP-1

Microscopic investigations demonstrated that GP-1 induces deposition of callose in tobacco leaves at concentrations of from 50 to $200 \mu \mathrm{g} / \mathrm{mL}$ (Fig. 6a). The first disseminations of callose appeared $30 \mathrm{~min}$ after the addition of elicitor. Sections containing callose exhibited bright blueish luminescence, which increased over time and reached a maximum of intensity $72 \mathrm{~h}$ after treatment with GP-1 (Fig. 6b).

Transcriptome changes after GP-1 treatment 
Transcriptome analysis showed significant differences in the expression levels of 564 genes between the GP-1-treated Nicotiana benthamiana and the control. Among the 564 genes, 460 were up-regulated, and 104 were down-regulated (Supplementary Figure 1). GO enrichment analysis of the differentially expressed genes demonstrated that these genes were significantly up-regulated and enriched in pathways, including their defence, immune reaction (Supplementary Figure 2). The enrichment analysis of these differentially expressed genes on the KEGG pathway (Supplementary Figure 4) revealed that numerous genes, which were involved in $\mathrm{Ca}^{2+}$ signalling, ROS, NO, MAPK, and SA signalling, exhibited significant up-regulation.

To further confirm the results of transcriptome sequencing, the transcript of several genes that involved in immune reactions were analyzed by qRT-PCR (Fig. 7). HSR203J, STR319, SGT, LOX, WIPK, CalS, and CaM5, that are involved in HR establishment, SA or JA synthesis, callose deposition, and $\mathrm{Ca}^{2+}$ signal pathway, were selectively picked out for examination. Results showed that all the examined genes were significantly up-regulated by GP-1 treatment (Fig. 7).

\section{Discussion}

Biological active molecules, such as oligosaccharides, polypeptides, and lipids can be recognized by receptors on the surfaces of plant cells and trigger plant defense responses, resulting in systemic resistance (Dewen, Q. et al., 2017). Among these inducers, chitosan has been well investigated and the anti-virus mechanism of chitosan has been studied thoroughly (Pichyangkura, R. \& S. Chadchawan, 2015; Hadwiger, L.A., 2013). A glycoprotein, GP-1, with high activity against TMV from Streptomyces sp. ZX01 was isolated in our lab (Zhang, G., et al., 2016). To further elucidate the immunity-inducing mechanism of GP-1, some early plant defense responses were examined in this study.

A burst in oxidative metabolism that leads to the accumulation of superoxide $\left(\mathrm{O}^{2-}\right)$ and $\mathrm{H}_{2} \mathrm{O}_{2}$ is considered a significant early event in the plant defense system and has been proposed as key factors in the control of both developmentally and environmentally induced PCD (Petrov, Hille et al. 2015). The rapid increase of $\mathrm{H}_{2} \mathrm{O}_{2}$ in both leaves and tobacco suspension cells treated by GP-1 (Fig. 2) proved a plant defense system was activated.

The production of ROS by NADPH oxidases are mainly controlled by $\mathrm{Ca}^{2+}$ via direct binding to EF-hand motifs and phosphorylation by $\mathrm{Ca}^{2+}$-dependent protein kinases (Kadota, Y., K. Shirasu, \& C. Zipfel, 2015). What's more, $\mathrm{Ca}^{2+}$ influx can also led to rapid production of $\mathrm{NO}$ and activation of mitogen-activated protein kinases (MAPKs) (Ma, W., et al., 2008). In this study, GP-1 was proved to be involved in $\mathrm{Ca}^{2+}$ mediated signaling (Fig. 3) and NO production (Fig. 4)

Plant hormones as well as microbial elicitors, such as chitosan ( Srivastava, N., et al.,2009), can modulate stomata, during which $\mathrm{NO}$ is a key element among the signaling elements leading to stomatal closure (Agurla, S., G. Gayatri, \& A.S. Raghavendra, 2014). Stomatal closure restricts the entry of pathogens into 
leaves and forms a part of plant defense response (Agurla, S., G. Gayatri, \& A.S. Raghavendra, 2014). In this study, the increased NO by GP-1 treatment indeed led to stomatal closure (Fig. 5).

Upon pathogen infection, callose is deposited in cell wall appositions, called Papillae, at the sites of attack to form effective chemical and physical defense barriers for pathogen invasion (Luna, E., et al., 2011). Purified pathogen-associated molecular patterns (PAMPs), including flg22, elf18 and chitosan, have been shown to induce callose deposits in leaves or cotyledons of Arabidopsis, which has emerged as an indicator of plant immune responses (Wu, S., L. Shan, \& P. He, 2014). As expected, GP-1 induced callose deposition like elicitors mentioned above (Fig. 6).

SAR and ISR share a lot of similarities both on result and in mechanisms, but the association to different hormone signaling pathways makes a clear discrimination between them-salicylic acid (SA) is the major modulator of SAR while JA and ET signaling pathways are the dominant regulators of ISR (Pieterse, C.M., et al., 2014). While these responses have distinct molecular signatures, they all involve ROS signaling (Perez, I.B. \& P.J. Brown, 2014). As the exact mechanism of GP-1 in plant protection could not be unraveled solely by the observation of ROS burst. So, the transcriptome difference (Supplementary Figures 1 to 3 ) and the expression of plant defense-related genes was investigated after GP-1 treatment (Fig. 7).

HSR203J plays a functional role in the establishment of the HR. The temporal and spatial patterns of HSR203J activation in leaves and roots inoculated with Pseudomonas solanacearum indicate that the HSR203J promoter exhibits a rapid (3 to $6 \mathrm{~h}$ post-inoculation) and high level of induction only in plant cells inoculated with the HR-inducing bacterial isolate (Pontier, D., et al., 2014). In this study, the rapid induction of HSR203J by GP-1 was also observed, supporting the establishment of HR and PCD by GP-1. As the promoter of HSR203J does not respond to various stress conditions and is only very weakly induced during compatible interactions (Pontier, D., et al., 2014), GP-1 may have similar function with incompatible pathogenic bacterium. STR319, as another marker for the HR (Keller, H., et al.,1998), participates in sesquiterpenoid biosynthesis and is also induced by GP-1 rapidly with a similar pattern with HSR203J.

The expression of SGT (UDP-Glc: SA glucosyltransferase), which converts SA to a conjugated and stable form (Chen, Z., et al., 2009), was induced by GP-1, indicating the SAR established by GP-1 (Zhang, G., et al., 2016) may be SA-dependent. By using Arabidopsis mutants impaired in jasmonic acid (JA) or ethylene (ET) signaling, it was demonstrated that JA and ET are central players in the regulation of ISR (Pieterse, C.M., et al., 2014). In plants, the step catalyzed by lipoxygenase (LOX) is regarded as a crucial step in octadecanoid and jasmonate biosynthesis (Otto, M., et al., 2016). Transcripts of LOX were induced by GP-1 indicating an increasing biosynthesis of JA. Wound-induced protein kinase (WIPK) is activated by biotic and abiotic stresses and positively regulate the biosynthesis of JA or ET while negatively regulating SA accumulation (Kobayashi, M., et al., 2010). Though GP-1 could enhance the biosynthesis pathways of both JA and SA, WIPK expression was still induced by GP-1 treatment (Fig. 7). This result 
supported a JA-dependent signal pathway was also involved in the plant protection by GP-1. This hypothesis was further confirmed by the increased contents of SA and JA after GP-1 treatment (Fig. 8).

As callose deposition was observed after GP-1 treatment, the expression of callose synthase (CalS) was further monitored. The results showed that GP-1 induced the expression of CalS with a similar pattern with that of HSR203J (Fig. 7), further proving the callose deposition effects of GP-1.

Its' well known that CaM involves in many cellular processes, such as, enzyme activity regulation, sexual regulation, cell division and differentiation, cytoskeleton and cell movement, photosynthesis, hormone response, nuclear enzyme system and gene expression. More and more studies have confirmed that the CaM signaling pathway plays an important role in abiotic stress, SAR, and disease resistance. AtCaM3 of Arabidopsis is an important member of the heat shock signaling pathway (Zhang et a1.2009). CaM4 and CaM1 of Soybean genes can accumulate proline and enhance plant salt and salt tolerance (Yoo et a1.2005). Up-regulation of calmodulin gene expression after tobacco is infected by TMV (Yamakawa et a1.2001). Silencing of CaCaM1 increases the susceptibility of pepper (C. annuum) to pathogens and viruses (Choi et a1.2009). The expression of two calmodulin genes SCaM4 and SCaM5 in soybean is strongly induced by pathogenic fungi (Heo et al.1999). So, the increased expression of CaM5 observed in this study indicated that the CaM5 was an important disease-resistant gene regulated by GP-1 to enhance the resistance of $N$. benthamiana.

Conclusion

This study explained the mechanism of the GP-1-induced resistance of tobacco to the TMV. Substantial GP-1 can be obtained by fermentation of Streptomyces sp. ZX01. This method is cost effective with simple extraction techniques and without subjection to external environmental conditions. In addition, GP-1 is highly active, safe for humans and animals, and is inexpensive to prepare. Therefore, this glycoprotein possesses significant potential for commercial agricultural applications.

\section{Methods}

Chemicals

3-amino,4-aminomethyl-2',7'-difluorescein, diacetate (DAF-FM DA), 2'7'-dichlorofluorescein diacetate (DCFH-DA) and Fluo-3AM were from Beyotime Institute of Biotechnology (Shanghai, China). All other reagents were obtained from Alfa Aesar, Tianjin Kermel Chemical Development Centre, or Beijing Chemical Plant.

The purification of the glycoprotein GP-1 was realised following the modified method of Zhang et al (2015). In short, the supernatant of Streptomyces sp. ZX01 culture was filtered using a $10 \mathrm{kDa}$ ultrafiltration membrane. The filtrate was purified by using DEAE-52 column $(10 \times 2 \mathrm{~cm})$. The $0.1 \mathrm{M} \mathrm{NaCl}$ eluent was collected, and then applied to a Sephadex G-75 gelfiltration column $(1.2 \mathrm{~cm} \times 100 \mathrm{~cm})$, and eluted with deionized water at a flow rate of $0.3 \mathrm{~mL} / \mathrm{min}$. Total glycoproteins identitied and collected by 
HPLC (Ailgent 1260, USA) with TSK-GEL G2000SW XL column $(7.8 \times 300 \mathrm{~mm}, 5 \mu \mathrm{m})$. The molecular weight of GP-1 approximately is $8.5 \mathrm{kDa}$. GP-1 were sterilized by filtration through a Millipore filter $(0.22$ $\mu \mathrm{m})$.

Cells culture and treatments

Tobacco suspension cells ( $N$. tabacum var. samsun NN) (The cells obtained from Academy of Agricultural Sciences) were routinely propagated and cultured as described previously (Wang, W., et al., 2008). For the experiments, cells were reinoculated ( $1 \% \mathrm{w} / \mathrm{v}$ inoculum) during their exponential growth phase. At the fourth day of culture, GP-1 was added to the medium.

Evans blue staining and quantification

To observe the dying cells in GP-1 induced tobacco leaves, Evans blue staining was performed as described (Xing, F., et al., 2013). Detached leaves were submerged in Evans blue solution $(0.25 \%, w / v)$ for $5 \mathrm{~h}$. Then the leaves were boiled in $95 \%$ ethanol for $15 \mathrm{~min}$ to remove the chlorophyll completely for observation and photos taking. The blue precipitates were solubilized with $1 \%(\mathrm{w} / \mathrm{v})$ SDS in $50 \%(\mathrm{v} / \mathrm{v})$ methanol at $50{ }^{\circ} \mathrm{C}$ for $20 \mathrm{~min}$ and quantified by measuring the absorbance at $600 \mathrm{~nm}$.

In vivo Detection of $\mathrm{H}_{2} \mathrm{O}_{2}$ and $\mathrm{ROS}$

The in vivo detection of $\mathrm{H}_{2} \mathrm{O}_{2}$ was carried out using 3,3'-diaminobenzidine (DAB) according to ThordalChristensen et al. (2010). DAB polymerizes locally as soon as it comes into contact with $\mathrm{H}_{2} \mathrm{O}_{2}$ in the presence of peroxidase, giving a reddish-brown polymer. $\mathrm{DAB}$ is taken up by living plant tissue and can be used to show $\mathrm{H}_{2} \mathrm{O}_{2}$ production when peroxidase activity is present (Thordal-Christensen, $\mathrm{H}_{\text {., }}$ et al., 2010). The leaves from tobacco were cut, placed in $1 \mathrm{mg} / \mathrm{mL}$ DAB-HCl, pH 3.8 (Sigma, MO, USA; \#D-8001) and incubated in the growth chamber for $8 \mathrm{~h}$ prior to sampling. When sampling occurred later than $8 \mathrm{~h}$ after treatment, the leaves were cut and placed in water at the time of inoculation. At specific time-points after treatment the DAB reactions were examined in leaves cleared in boiling ethanol (96\%) for $10 \mathrm{~min}$. The samples were stored and examined in $96 \%$ ethanol. $\mathrm{H}_{2} \mathrm{O}_{2}$ is visualized as a reddish-brown coloration.

When applied to intact cells, the nonionic, nonpolar DCFH-DA crosses cell membranes and is hydrolyzed enzymatically by intracellular esterases to nonfluorescent DCFH. In the presence of ROS, DCFH is oxidized to highly fluorescent dichlorofluorescein (DCF). Therefore, the intracellular DCF fluorescence can be used as an index to quantify the overall ROS in cells (Wang, H. \& J.A. Joseph, 1999). Five $\mu M$ (final concentration) DCFH-DA solubilized in ethanol were added to the $1 \mathrm{~mL}$ tobacco cell suspension cultures and incubated on a shaker at room temperature in the dark for $1 \mathrm{~h}$ and then rinsed twice with fresh suspension buffer to wash off excessive fluorophore probe. GP-1 $(100 \mu \mathrm{g} / \mathrm{mL})$ was added to the cells and incubated in microplate for 30 min before imaging with $488 \mathrm{~nm}$ excitation and $525 \mathrm{~nm}$ emission filters.

Determination of $\mathrm{H}_{2} \mathrm{O}_{2}$ 
Hydrogen peroxide was extracted from plant tissues as described by Patterson et al. (1984). Fresh leaves or suspension cells $(0.5 \mathrm{~g})$ were homogenized in cold acetone in $1 \mathrm{~mL}$ acetone. Titanium reagent $(20 \%$ $\mathrm{TiCl}_{2}$ in $\mathrm{HCl}$ ) was added to a known volume of extract supernatant to give a $\mathrm{Ti}$ (IV) concentration of $2 \%$. The $\mathrm{Ti}-\mathrm{H}_{2} \mathrm{O}_{2}$ complex, together with unreacted $\mathrm{Ti}$, was then precipitated by adding $0.2 \mathrm{~mL} 17 \mathrm{M}$ ammonia solution for each $1 \mathrm{~mL}$ of extract. The precipitate was washed five times with acetone by resuspension, drained, and dissolved in $2 \mathrm{~N} \mathrm{H}_{2} \mathrm{SO}_{4}(3 \mathrm{~mL})$. The absorbance of the solution was measured at $410 \mathrm{~nm}$ against blanks which had been prepared similarly but without plant tissue.

Measurement of nitric oxide (NO) and cytoplasmic $\mathrm{Ca}^{2+}\left(\left[\mathrm{Ca}^{2+}\right]_{\mathrm{cyt}}\right)$

NO accumulation was determined using the fluorophore probe DAF-FMDA as described previously (Foresi, N., et al., 2010). Briefly, the tobacco suspension cells were incubated with $5 \mu \mathrm{M} \mathrm{DAF-FMDA}$ for $1 \mathrm{~h}$ in the dark at $25^{\circ} \mathrm{C}$ on a rotary shaker $(120 \mathrm{rpm})$ and then rinsed twice with fresh suspension buffer to wash off excessive fluorophore probe. Cells were then transferred into 96 -well plates $(100 \mu \mathrm{L}$ of cells per well), and treated with GP-1 in the dark. NO production was measured using a 96-well Gemini EM Fluorescence Microplate Reader with $495 \mathrm{~nm}$ excitation and $515 \mathrm{~nm}$ emission filters. Fluorescence was expressed as relative fluorescence units. $\left[\mathrm{Ca}^{2+}\right]_{\mathrm{cyt}}$ accumulation were determined by corresponding fluorescent probe Fluo-3AM $(5 \mu \mathrm{M})$ using the same method with NO except that the $\left[\mathrm{Ca}^{2+}\right]_{\text {cyt }}$ experiment was operated at $37^{\circ} \mathrm{C}$, the excitation and emission for $\mathrm{Ca}^{2+}$ were 506 and $526-\mathrm{nm}$. For each treatment, measurements of $\mathrm{NO}$ and $\mathrm{Ca}^{2+}$ production over time were performed on the same batch of cells.

Stomatal closure in epidermal strips

Stomatal bioassays were carried out essentially as described by Srivastava et al.(Srivastava, N., et al., 2009) with modification. The abaxial (lower) epidermis of tobacco leaves was peeled off and first incubated in MES buffer ( $10 \mathrm{mM}$ MES-KOH and $20 \mathrm{mM} \mathrm{KCl}, \mathrm{pH} 6.25)$ for $3 \mathrm{~h}$ under conditions promoting stomatal opening (at $25^{\circ} \mathrm{C}$, under a photon flux density of $250 \mu \mathrm{mol} / \mathrm{m}^{2} / \mathrm{s}$ ) to open the stomata. The epidermis was then transferred to MES buffer in the presence of abscisic acid (ABA, $10 \mu \mathrm{M})$ or GP-1 ( 0 , $50,100,200 \mu \mathrm{g} / \mathrm{mL}$ ) for another $3 \mathrm{~h}$ in the same conditions. Stomatal closure was observed under the microscope and pictures were taken of random regions. The width of the stomatal aperture was measured using the software ImageJ for Windows. The experiments were repeated at least three times, making each measurement of stomatal aperture an average of at least 90 stomata.

Quantitative real time-polymerase chain reaction (qRT-PCR)

Total RNA of tobacco leaves was extracted using TaKaRa MiniBEST Plant RNA Extraction Kit (TAKARA, 9769S). PrimeScriptTM RT reagent Kit with gDNA Eraser (TAKARA, RR047Q) was applied to eliminate DNA in total RNA and reverse transcription. The qRT-PCR amplification was performed using iCycler IQTM Real Time PCR Detection System (Bio-rad, USA). Each reaction contained a mixture of $1 \mu \mathrm{L}$ of template, $12.5 \mu \mathrm{L}$ of SYBR Premix Ex TaqTM II, $1 \mu \mathrm{L}$ of forward primer $(10 \mu \mathrm{M})$ and reverse primer (10 $\mu \mathrm{M})$, and $9.5 \mu \mathrm{L}$ of nuclease-free water (Takara, Japan). The primers of genes and their descriptions, 
including HSR203J, STR319, SGT, CaIS, LOX1, WIPK, and Actin, were shown in Table 1. The reaction mixture was incubated for $30 \mathrm{~s}$ at $95^{\circ} \mathrm{C}$, and for 40 cycles of $10 \mathrm{~s}$ at $95^{\circ} \mathrm{C}$ and $30 \mathrm{~s}$ at $56^{\circ} \mathrm{C}$. Each assay included three technical and two biological replicates. The relative gene expression was quantified by using $2^{-\Delta \Delta C t}$ method (Livak, K.J. \& T.D. Schmittgen, 2001). At each time point, the relative expression of a gene from the treatment was compared against that from the control.

Library construction and RNA-seq analysis

Our previous study found that the expression level of most resistant genes reached the highest value at $11 \mathrm{~h}$ after GP-1 treatment. Therefore, in this study, the transcriptome was measured in $N$. benthamiana that were treated with GP-1 for $11 \mathrm{~h}$. $N$. benthamiana was treated with $100 \mu \mathrm{g} \mathrm{mL}^{-1} \mathrm{GP}-1$ and water, respectively. Five N. benthamiana leaves were mixed as a biological repeat, and repeated three times in each group. Total RNA was extracted using the TRIzol reagent. Library construction was performed according to instructions of NEBNext ${ }^{\circledR}$ Ultra ${ }^{T M}$ RNA Library Prep Kit for RNA Illumina and sequenced on Illumina Hiseq ${ }^{\mathrm{TM}} 2500 /$ Miseq $^{\mathrm{TM}}$ sequencer. Raw reads in FASTQ format were first processed through inhouse Perl scripts. Clean data were obtained by removing low-quality reads and reads containing ploy- $\mathrm{N}$ from raw data (Bolger et al., 2014). Clean reads were mapping to the reference sequence (transcript Homo_sapiens. GRCh38.p10) by Bowtie 2 v2.1.0 (Langmead et al., 2012), and the expression levels were analyzed by samtools v0.1.19 (Li et al., 2009). Next the DEG seq v1.20.0 (Wang et al., 2010) package of the MARS (MA-plot-based method with Random sampling model) model was used to analyze the differentially expressed genes between differently samples. The Gene Ontology database was used for Genetic Ontology (GO) analyses and GO enrichment. The RPKM values of all the combined differential genes were combined in each experimental group/sample for hierarchical clustering analyzing. KEGGbased analysis used the blastall program (http://www.genome.jp/kegg) for the KEGG database.

Determination of salicylic acid and jasmonic acid

After treated with $100 \mu \mathrm{g} \mathrm{mL}^{-1}$ of GP-1 by spraying, tobacco leaves were used for SA extraction and quantified by HPLC as described by Marianne (2002). The contents of jasmonic acid in leaves were measured by gas chromatograph according to the method described by Lan et al. (2004) and Deng et al. (2009).

\section{Abbreviations}

TMV: tobacco mosaic virus

HR: hypersensitive response

PCD: programmed cell death

SAR: systemic acquired resistance, 
DAF-FM DA: 3-amino,4-aminomethyl-2',7'-difluorescein, diacetate,

DCFH-DA: 2'7'-dichlorofluorescein diacetate

RT-PCR: Reverse transcription-polymerase chain reaction

NO: Nitric oxide

ROS: reactive oxygen species

EGTA: Ethylene Glycol Tetraacetic Acid

\section{Notes}

\section{Funds}

We greatly appreciate the funding provided by The Shaanxi Science and Technology Research and Development Program (2019NY-198), National Key Technology R\&D Program of China (2014BAD23B01), National Natural Science Foundation of China (NSFC 31201536), Shaanxi Key Project of Research and Development Plan of China囚2017ZDCXL-NY-03-01 怄Undergraduate Scientific and Technological Innovation Project of China (201710712006 and 2201810712082).

Availability of data and materials

All data generated or analysed during this study are included in this published article (and its supplementary information files).

Authors' contributions

LRH, YBS, and JTF conceived and designed the experiments. YBS, MW, Xing Zhou and XCH performed the experiments. LRH, YBS, and Xing Zhang analyzed the data. LRH, YBS, and JTF wrote the paper. All authors read and approved the final manuscript.

Ethics approval and consent to participate

Not applicable.

Consent for publication

Not applicable.

Competing interests

The authors have declared that no competing interests exist. 


\section{References}

Agurla, S., Gayatri, G., Raghavendra, A. S. (2014). Nitric oxide as a secondary messenger during stomatal closure as a part of plant immunity response against pathogens. Nitric Oxide, 43, 89-96. https://doi.org/10.1016/j.niox.2014.07.004

Bouranis, D. L., Chorianopoulou, S. N., Kollias, C., Maniou, P., Protonotarios, V. E., Siyiannis, V. F., et al. (2006). Dynamics of aerenchyma distribution in the cortex of sulfate-deprived adventitious roots of maize. Ann Bot, 97(5), 695-704. https://doi.org/10.1093/aob/mcl024

Bolger A M , Lohse M , Usadel B. (2014). Trimmomatic: a flexible trimmer for Illumina sequence data[J]. Bioinformatics, 30(15):2114-2120. https://10.1093/bioinformatics/btu170

Chen, Z., Zheng, Z., Huang, J., Lai, Z., Fan, B. (2009). Biosynthesis of salicylic acid in plants. Plant Signaling \& Behavior, 4(6), 493-496. https://doi.org/10.4161/psb.4.6.8392

Coll NS, Epple P, Dangl JL. (2011). Programmed cell death in the plant immune system. Cell Death and Differentiation, 18(8), 1247-56.

https://doi.org/ 10.1038/cdd.2011.37

Faoro, F., \& Gozzo, F. (2015). Is modulating virus virulence by induced systemic resistance realistic?. Plant Science, 234, 1-13.

https://doi.org/ 10.1016/j.plantsci.2015.01.011

Foresi, N, CorreaAragunde, N, Parisi, G, Caló, G, Salerno, G, Lamattina, L. (2010). Characterization of a nitric oxide synthase from the plant kingdom: no generation from the green alga ostreococcus tauri is light irradiance and growth phase dependent. The Plant Cell, 22(11), 3816-3830.

https://doi.org/ 10.1105/tpc.109.073510

Frederickson Matika, D. E., Loake, G. J. (2013). Redox regulation in plant immune function. Antioxid Redox Signal, 21(9), 1373-1388.

https://doi.org/ 10.1089/ars.2013.5679

Friedrich, L., Lawton, K. W., Masner, P., Specker, N., Rella, M. G., Meier. (1996). A benzothiadiazole derivative induces systemic acquired resistance in tobacco. Plant Journal, 10(1), 61-70.

Foyer CH, Lopez-Delgado H, Dat JF, Scott IM (1997). Hydrogen peroxide- and glutathione-associated mechanisms of acclimatory stress tolerance and signalling. Physiol Plant 100: 241-254.

https://doi.org/10.1034/j.1399-3054.1997.1000205.x 
Gong M, Van der Luit AH, Knight MR, Trewavas AJ (1998). Heat-shock-induced changes in intracellular $\mathrm{Ca} 2+$ level in tobacco seedlings in relation to thermotolerance. Plant Physiol 116: 429-437.

https://doi.org/10.1104/pp.116.1.429

Gust, A. A., Biswas, R., Lenz, H. D., Rauhut, T., Ranf, S., Kemmerling, B., et al. (2007). Bacteria-derived peptidoglycans constitute pathogen-associated molecular patterns triggering innate immunity in arabidopsis.Journal of Biological Chemistry, 282(44), 32338. https://doi.org/10.1074/jbc.M704886200

Hadwiger, L. A. (2013). Multiple effects of chitosan on plant systems: solid science or hype. Plant Science And International Journal of Experimental Plant Biology, 208(208C), 42-49.

https://doi.org/10.1016/j.plantsci.2013.03.007

Heinrich Kauss. (1985). Chitosan-elicited callose synthesis in soybean cells as a ca² ${ }^{2}$-dependent process. Plant Physiology, 77(3), 544-551. https://doi.org/10.1104/pp.77.3.544 \

Heo WD,Lee SH, Kim MC, Kim JC, Chung WS, Chun HJ, Lee KJ, Park CY Park HC, Choi JY, Cho MJ. 1999. Involvement of specific calmodulin isoforms in salicylic acid-independent activation of plant disease resistance responses. Proceedings of the National Academy of Sciences ofthe United States of America 96(2): 766-771.

Hong Wang, James A Joseph. (1999). Quantifying cellular oxidative stress by dichlorofluorescein assay using microplate reader 1. Free Radic Biol Med, 27(5-6), 612-616. https://doi.org/10.1016/S08915849(99)00107-0

Kadota, Y., Shirasu, K., Zipfel, C. (2015). Regulation of the nadph oxidase rbohd during plant immunity. Plant \& Cell Physiology, 56(8), 1472. https://doi.org/10.1093/pcp/pcv063

Keller, H., Czernic, P., Ponchet, M., Ducrot, P. H., Back, K., Chappell, J., et al. (1998). Sesquiterpene cyclase is not a determining factor for elicitor- and pathogen-induced capsidiol accumulation in tobacco. Planta,205(3), 467-476.

Kobayashi, M., Seo, S., Hirai, K., Yamamotokatou, A., Katou, S., Seto, H., et al. (2010). Silencing of wipk and sipk mitogen-activated protein kinases reduces tobacco mosaic virus accumulation but permits systemic viral movement in tobacco possessing the $n$ resistance gene. Molecular plant-microbe interactions : MPMI, 23(8), 1032. https://doi.org/ 10.1094/MPMI-23-8-1032

Köhle, H., Young, D. H., Kauss, H. (1984). Physiological changes in suspension-cultured soybean cells elicited by treatment with chitosan.Plant Science Letters, 33(2), 221-230. https://doi.org/10.1016/03044211(84)90012-9

Langmead, B., \& Salzberg, S. L. (2012). Fast gapped-read alignment with Bowtie 2. Nature methods, 9(4), 357-359. 
Livak KJ, Schmittgen TD. (2001). Analysis of relative gene expression data using real-time quantitative pcr and the 2(-delta delta c(t)) method.Methods-A Companion To Methods in Enzymology, 25(4), 402-408. https://doi.org/10.1006/meth.2001.1262

Li, H., Handsaker, B., Wysoker, A., Fennell, T., Ruan, J., Homer, N., ... \& Durbin, R. (2009). The sequence alignment/map format and SAMtools.Bioinformatics, 25(16), 2078-2079. https://doi.org/10.1046/j.14401665.1999.0178e.x

Luna, E., Pastor, V., Robert, J., Flors, V., Mauch-Mani, B., Ton, J. (2011). Callose deposition: a multifaceted plant defense response. Mol Plant Microbe Interact, 24(2), 183-193. https://doi.org/10.1094/MPMI-07-100149

Luvisi, A., Panattoni, A., Materazzi, A., Bellis, L. D. (2017). Chemical outbreak for tobacco mosaic virus control. International Journal of Agriculture \& Biology, 19, 792-800.

https://doi.org/10.17957/IJAB/15.0365

Luna, E., Pastor, V., Robert, J., Flors, V., Mauch-Mani, B., Ton, J. (2011). Callose deposition: a multifaceted plant defense response. Mol Plant Microbe Interact, 24(2), 183-193. https://doi.org/10.1094/MPMI-07-100149

Ma, W., Smigel, A., Tsai, Y. C., Braam, J., Berkowitz, G. A. (2008). Innate immunity signaling: cytosolic ca2+ elevation is linked to downstream nitric oxide generation through the action of calmodulin or a calmodulin-like protein. Plant Physiology, 148(2), 818-828. https://doi.org/10.1104/pp.108.125104

Markus, O., Christin, N., Wolfgang, B., Claus, W., Bettina, H. (2016). Activity regulation by heteromerization of arabidopsis allene oxide cyclase family members. Plants, 5(1), 3.

https://doi.org/10.3390/plants5010003

Marianne, C.V., Nynke, B., Federica, D., Huub, J.M.L., John, F.B., Robert, V. (2002).

Method for the extraction of the volatile compound salicylic acid from tobacco leaf material. Phytochem Analysis 13:45-50. https://doi.org/10.1002/pca.615

Malamy J, Hennig J, Klessig DF (1992). Temperature-dependent induction of salicylic acid and its conjugates during the resistance response to tobacco mosaic virus infection. Plant Cell 4:359-366. https://doi.org/10.2307/3869546

Ouyang, G., Chen, Z., Cai, X. J., Song, B. A., Bhadury, P. S., Yang, S., et al. (2008). Synthesis and antiviral activity of novel pyrazole derivatives containing oxime esters group. Bioorg Med Chem, 16(22), 96999707. https://doi.org/10.1016/j.bmc.2008.09.070 
Patterson, B. D., Macrae, E. A., Ferguson, I. B. (1984). Estimation of hydrogen peroxide in plant extracts using titanium(iv). Analytical Biochemistry, 139(2), 487-492. https://doi.org/10.1016/00032697(84)90039-3

Petrov, V., Hille, J., Muellerroeber, B., Gechev, T. S. (2015). Ros-mediated abiotic stress-induced programmed cell death in plants. Frontiers in Plant Science, 6(69), 69.

https://doi.org/10.3389/fpls.2015.00069

Prasad V, Mishra SK, Srivastava S, Srivastava A. (2014). A virus inhibitory protein isolated from cyamopsis tetragonoloba (I.) taub. upon induction of systemic antiviral resistance shares partial amino acid sequence homology with a lectin. Plant Cell Reports, 33(9), 1467-78.

https://doi.org/10.1007/s00299-014-1630-7

Pieterse CM, Zamioudis C, Berendsen RL, Weller DM, Van Wees SC, Bakker PA. (2014). Induced systemic resistance by beneficial microbes.Annual Review of Phytopathology, 52(52), 347-375.

https://doi.org/10.1146/annurev-phyto-082712-102340

Perez, I. B., Brown, P. J. (2014). The role of ros signaling in cross-tolerance: from model to crop. Frontiers in Plant Science, 5(754), 754. https://doi.org/ https://doi.org/10.3389/fpls.2014.00754

Pichyangkura, R., Chadchawan, S. (2015). Biostimulant activity of chitosan in horticulture. Scientia Horticulturae, 196, 49-65. https://doi.org/10.1016/j.scienta.2015.09.031

Pontier, D., Godiard, L., Marco, Y., Roby, D. (2010). Hsr203j, a tobacco gene whose activation is rapid, highly localized and specific for incompatible plant/pathogen interactions. Plant Journal, 5(4), 507-521. https://doi.org/10.1046/j.1365-313X.1994.5040507.x

Petrov, V., J. Hille, B. Mueller-Roeber and T. S. Gechev (2015). "ROS-mediated abiotic stress-induced programmed cell death in plants." Front Plant Sci 6: 69.

Qiu, D., Dong, Y., Zhang, Y., Li, S., Shi, F. (2017). Plant immunity inducer development and application. Molecular plant-microbe interactions : MPMI, 30(5), 355. https://doi.org/10.1094/MPMI-1116-0231-CR

Srivastava, N., Gonugunta, V. K., Puli, M. R., Raghavendra, A. S. (2009). Nitric oxide production occurs downstream of reactive oxygen species in guard cells during stomatal closure induced by chitosan in abaxial epidermis of pisum sativum. Planta, 229(4), 757-765. https://doi.org/10.1007/s00425-008-08555

Thordal-Christensen, H., Zhang, Z., Wei, Y., Collinge, D. B. (2010). Subcellular localization of h2o2 in plants. h2o2 accumulation in papillae and hypersensitive response during the barley-powdery mildew interaction. Plant Journal, 11(6), 1187-1194. https://doi.org/10.1046/j.1365-313X.1997.11061187.x 
Vlot, A.C., Dempsey, D.A., and Klessig, D.F. (2009). Salicylic acid, a multifaceted hormone to combat disease. Annu. Rev. Phytopathol. 47, 177-206. https://doi.org/10.1146/annurev.phyto.050908.135202

Wang, W., Li, S., Zhao, X., Du, Y., Lin, B. (2008). Oligochitosan induces cell death and hydrogen peroxide accumulation in tobacco suspension cells. Pesticide Biochemistry \& Physiology, 90(2), 106-113. https://doi.org/10.1016/j.pestbp.2007.10.003

Wang, Y., Loake, G. J., Chu, C. (2013). Cross-talk of nitric oxide and reactive oxygen species in plant programed cell death. Frontiers in Plant Science, 4(314), 314. https://doi.org/10.3389/fpls.2013.00314

Wang, L., Feng, Z., Wang, X., Wang, X., \& Zhang, X. (2010). DEGseq: an R package for identifying differentially expressed genes from RNA-seq data. Bioinformatics, 26(1), 136-138. https://doi.org/10.1093/bioinformatics/btp612

W.H. Deng, Y.B. Shen, H.J. Chen, Z.Y. Li, X.N. Jiang, Effects of dendrolimus punctatus feeding and methyl jasmonate (MeJA)- or terpenes fumigation on abscisic acid and jasmonic acid contents in Pinus massoniana seedling needles, Chin. J. Appl. Ecol. 20 (2009) 1166-1170.

Wu, S., Shan, L., He, P. (2014). Microbial signature-triggered plant defense responses and early signaling mechanisms. Plant Science, 228, 118-126. https://doi.org/10.1016/j.plantsci.2014.03.001

Xing, F., Li, Z., Sun, A., Xing, D. (2013). Reactive oxygen species promote chloroplast dysfunction and salicylic acid accumulation in fumonisin b1-induced cell death. Febs Letters, 587(14), 2164-2172. https://doi.org/10.1016/j.febslet.2013.05.034

Yamakawa H, Mitsuhara 1, Ito N, Seo S, Kamada H囚Ohashi Y. (2001).Transcriptionally and posttranscriptionally regulated response of 13 calmodulin genes to tobacco mosaic virus-induced cell death and wounding in tobacco plant. European Journal of Biochemistry. 268(14): 3916-3929

Y.P. Lan, Z.H. Han, X.F. Xu. (2004). Accumulation of jasmonic acid in apple seedlings under water stress, Acta Hortic. Sin. 31,16-20.

Yosef, E. , Politi, R. , Choi, M. H. , \& Shifman, J. M. . (2009). Computational design of calmodulin mutants with up to 900-fold increase in binding specificity. Journal of Molecular Biology, 385(5), 0-1480.

https://doi.org/10.1016/j.jmb.2008.09.053

Yonghui Ge, Kaixing Liu, Jianxin Zhang, Shuzhen Mu, Xiaojiang Hao. (2012). The limonoids and their antitobacco mosaic virus (tmv) activities from munronia unifoliolata oliv. Journal of Agricultural and Food Chemistry, 60(17), 4289-4295. https://doi.org/10.1021/jf205362d

Yoo JH, Park CY, Kim JC, Heo WD, Cheong MS, Park HC, Kim MC, Moon BC, Choi MS, Kang YH, Lee JH, Kim HS, Lee SM, Yoon HW, Lim CO, Yun DJ, Lee SY, Chung WS, Cho MJ. (2005). Direct interaction of a 
divergent CaM isoform and the transcription factor, MYB2, enhances salt tolerance in Arabidopsis. Journal of Biological Chemistry ?80(5): 3697-3706.

Zhang, G., Han, L., Zhang, G., Zhang, X., Feng, J. (2015). Purification and characterization of a novel glycoprotein from streptomyces sp. zx01.International Journal of Biological Macromolecules, 78(JUL), 195-201. https://doi.org/10.1016/j.jjbiomac.2015.04.012

Zhang W, Zhou RG, Gao YJ, Zheng SZ, Xu P, Zhang SQ, Sun DY.( 2009). Molecular and Genetic Evidence for the Key Role of AtCaM3 in Heat-Shock Signal Transduction in Arabidopsis Plant Physiology 149(4): 1773-1784.

Zhang, G., Feng, J., Han, L., Xing, Z. (2016). Antiviral activity of glycoprotein gp-1 isolated from streptomyces kanasensis, zx01.International Journal of Biological Macromolecules, 88, 572-577. https://doi.org/10.1016/j.ijbiomac.2016.04.038

Zipfel, C. (2014). Plant pattern-recognition receptors. Trends in Immunology, 35(7), 345-351. https://doi.org/10.1016/j.it.2014.05.004

Zuppini, A., Baldan, B., Millioni, R., Favaron, F., Navazio, L., Mariani, P. (2010). Chitosan induces ca ${ }^{2+}$ mediated programmed cell death in soybean cells. New Phytologist, 161(2), 557-568. https://doi.org/10.1046/j.1469-8137.2003.00969.x

\section{Table}

Table 1 Primers used in this study 


\begin{tabular}{lll}
\hline Gene & Primers (5' to 3') & GenBank Acc. No. \\
\hline HSR203J & Forward: AGCTAGAACAAGAGCAAACCCC & X77136.1 \\
& Reverse: CCGCCACACAGTACAAATAAGG & \\
STR319 & Forward: TCGTATTTGGGCATGAAGTCCGTTA & Y08847 \\
& Reverse: GGAGTCCACAAGCAGGGCAATAATG & \\
\hline SGT & Forward: GGTGTTTTCTCACGCACT & AJ538414 \\
& Reverse: GGTTGATCTGACCATTGC & \\
\hline CalS & Forward: GTTCGGGTTTCAGAGGGATA & AF304372.2 \\
& Reverse: CGTCAAGCTTGTTAAGTGGC & DQ460188 \\
\hline LOX & Forward: AGGCAGTGTTGAAGGATTGG & \\
& Reverse: CTCTTGTTGGTGCTTGTTGG & AB052964 \\
\hline WIPK & Forward: TCACTACCAAGTATCGTCCTCC & \\
& Forward: GATGGTGTCAGCCACACTGTC & \\
\hline CAM5 & Forward: & \\
& AGCCGATTTCAACAA 016614794.1
\end{tabular}

\section{Figures}



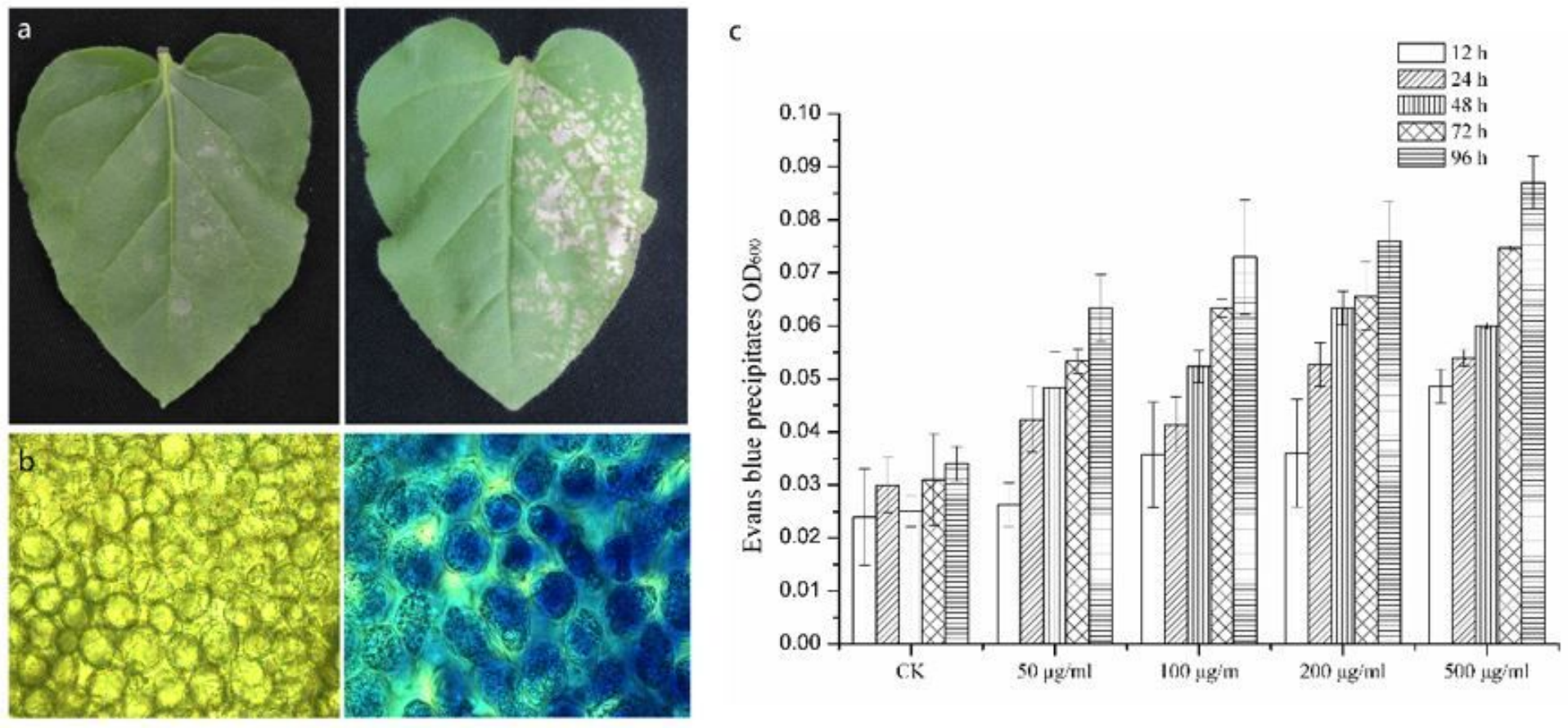

Figure 1

HR and PCD induced by GP-1. (a) HR in tobacco leaves was observed at $24 \mathrm{~h}$ post-infiltration with 50 $\mu \mathrm{g} / \mathrm{mL}$ (left) or $100 \mu \mathrm{g} / \mathrm{mL}$ (right). Water control was conducted on the left half of each leaf. (b) GP-1 induced cell death in infiltrated areas was stained blue (right), water treatment areas could not be stained by dye (left). (c) Quantification of cell death using Evans blue precipitates. Different concentrations of GP-1 were applied on tobacco leaves and samples were collected at different time points. 

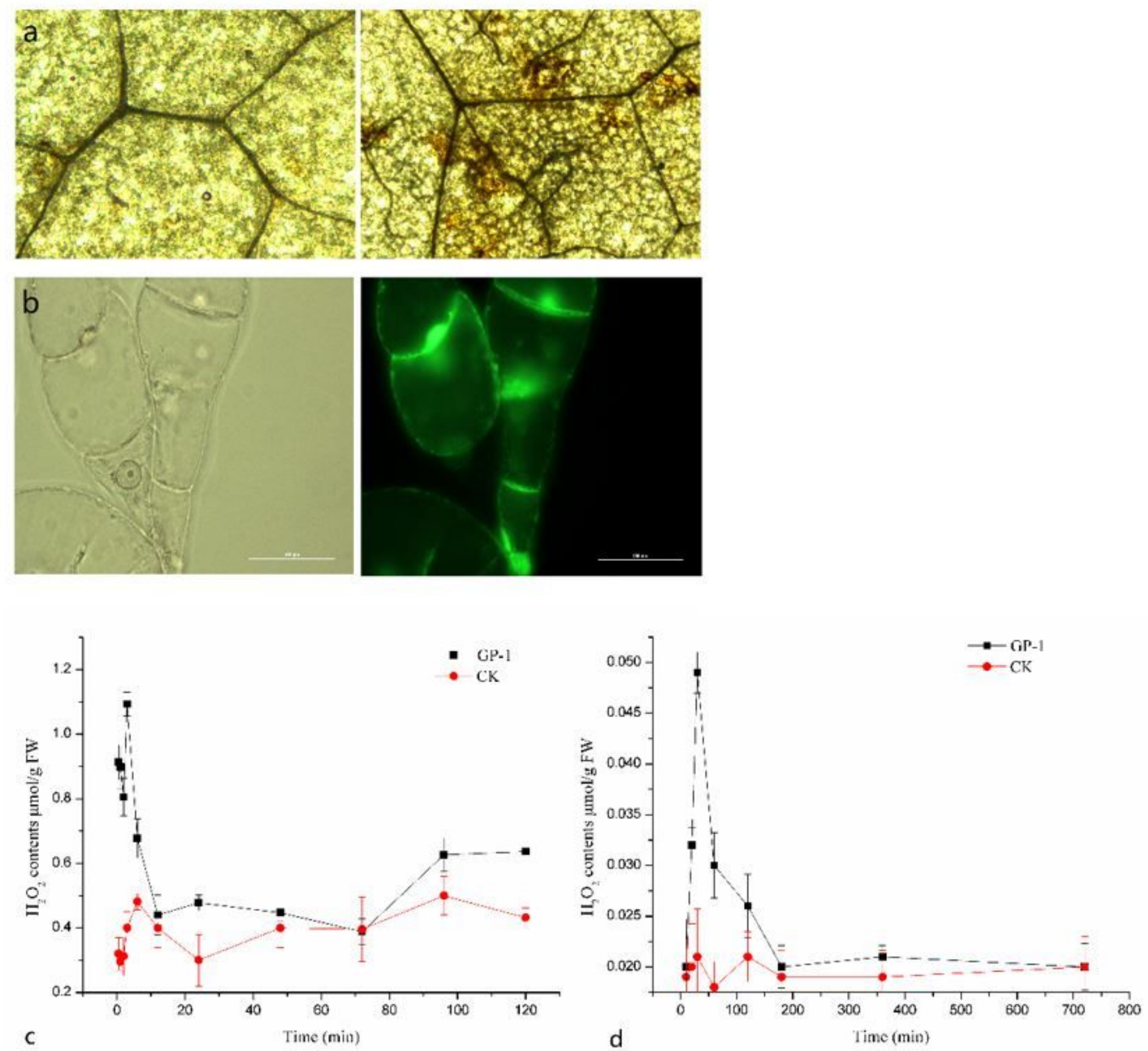

\section{Figure 2}

Induction of ROS production by GP-1. The invivo detection of $\mathrm{H} 2 \mathrm{O} 2$ was carried out using DAB in tobacco leaves (a) or using DCFH-DA in tobacco suspension cells (b) after $100 \mu \mathrm{g} / \mathrm{ml} \mathrm{GP}-1$ treatment for $8 \mathrm{~h}$. Quantification of H2O2 in tobacco leaves (c) or suspension cells (d) treated by $100 \mu \mathrm{g} / \mathrm{ml} \mathrm{GP}-1$ was conducted using titanium (IV). 


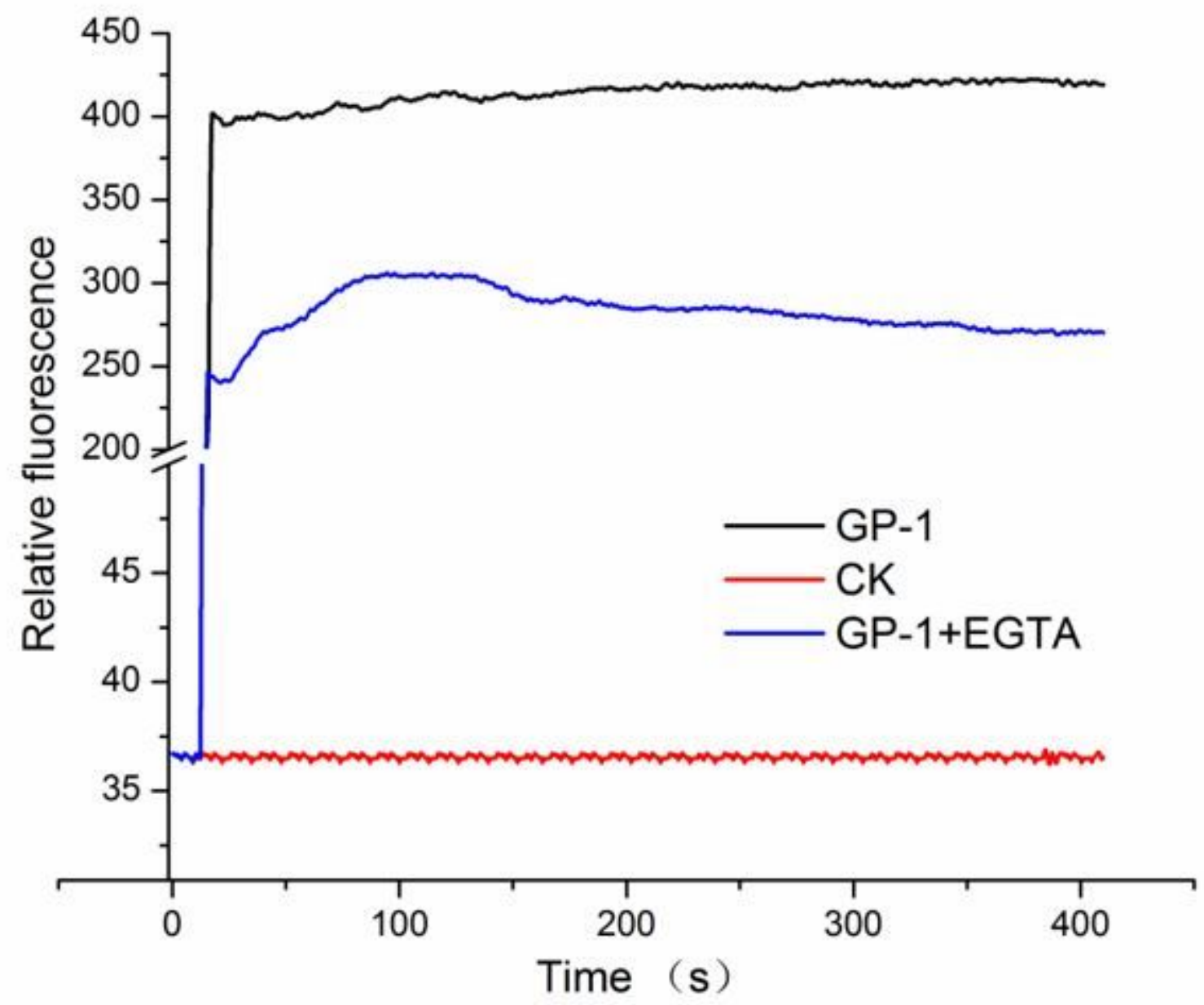

Figure 3

Elevation of [Ca2+]cyt induced by GP-1. The tobacco suspension cells were incubated with $5 \mu \mathrm{M}$ Fluo3AM for $1 \mathrm{~h}$ before GP-1 $(100 \mu \mathrm{g} / \mathrm{mL})$ treatment, [Ca2+]cyt production was measured using a 96 -well microplate with $506 \mathrm{~nm}$ excitation and $526 \mathrm{~nm}$ emission filters at different time points. 
a

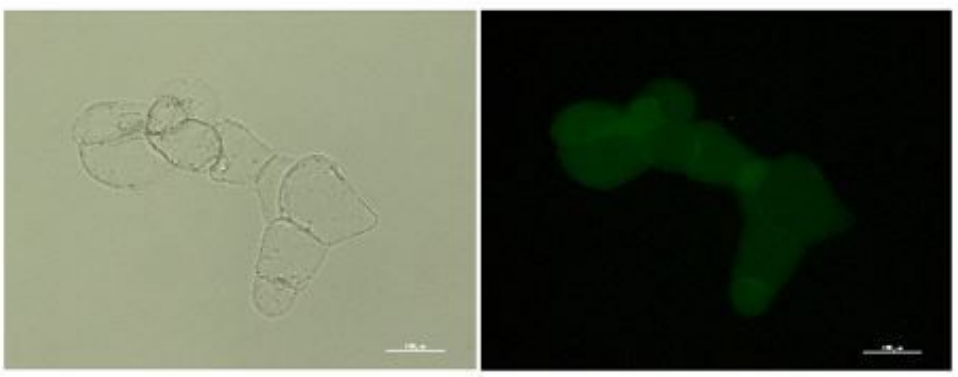

b

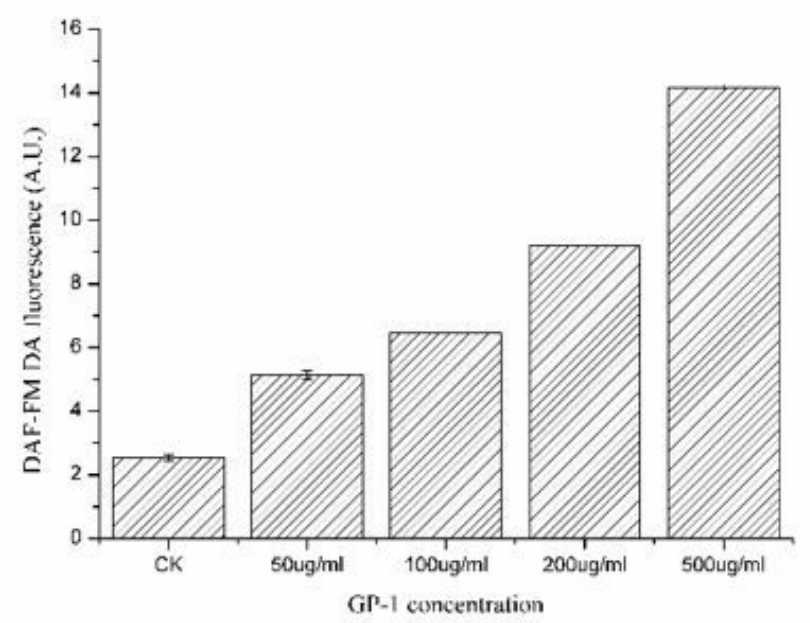

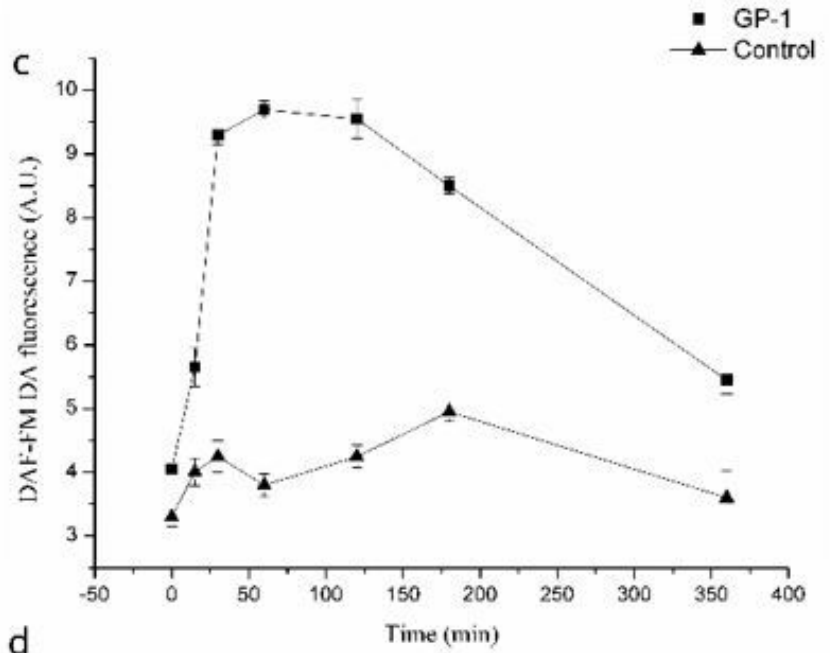

d

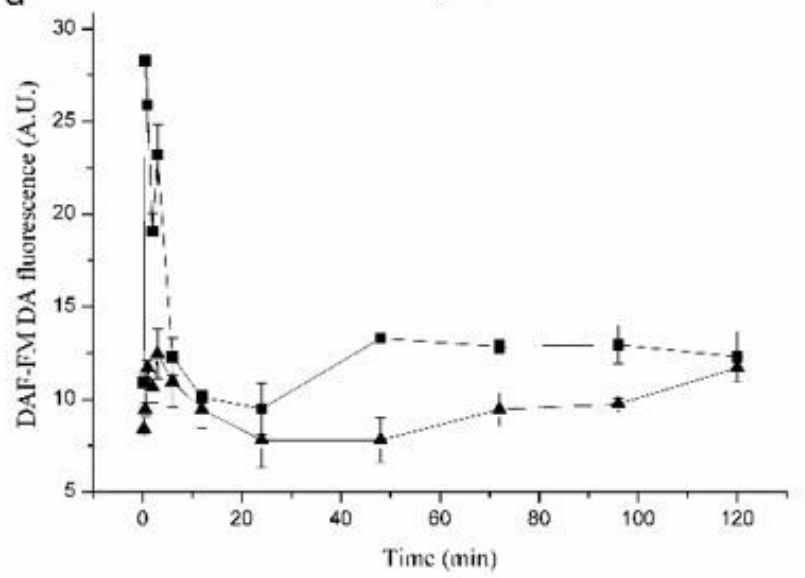

Figure 4

GP-1 induced NO production. (a) NO accumulation was visualized using the fluorophore probe DAFFMDA. (b) NO production was GP-1 concentration dependent. DAF-FMDA fluorescence was determined after GP-1 treatment for $30 \mathrm{~min}$. With the course of time, NO accumulation in tobacco suspension cells (c) and leaves (d) was determined after GP-1 $(100 \mu \mathrm{g} / \mathrm{mL})$ treatment. 


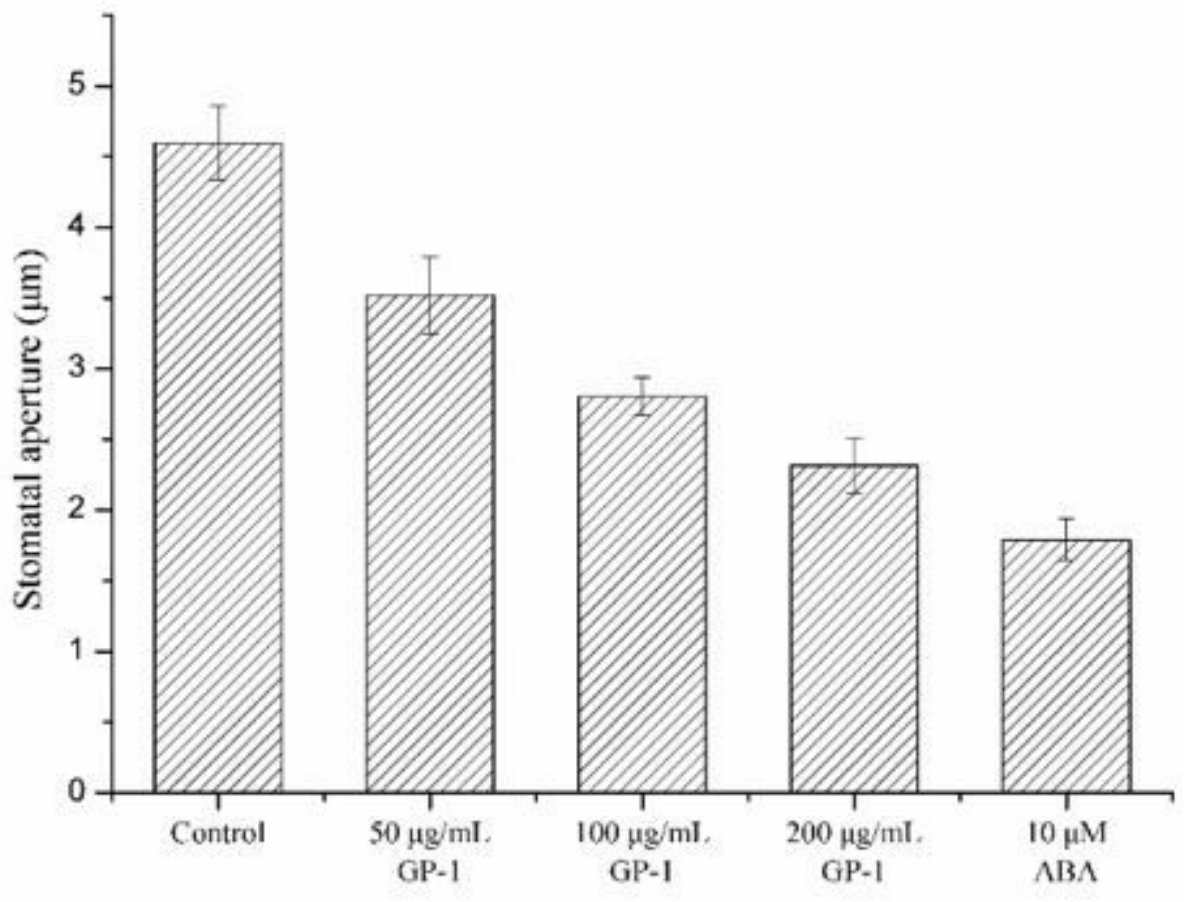

Figure 5

Stomatal aperture was reduced in diameter after GP-1 or ABA treatment for $3 \mathrm{~h}$. 

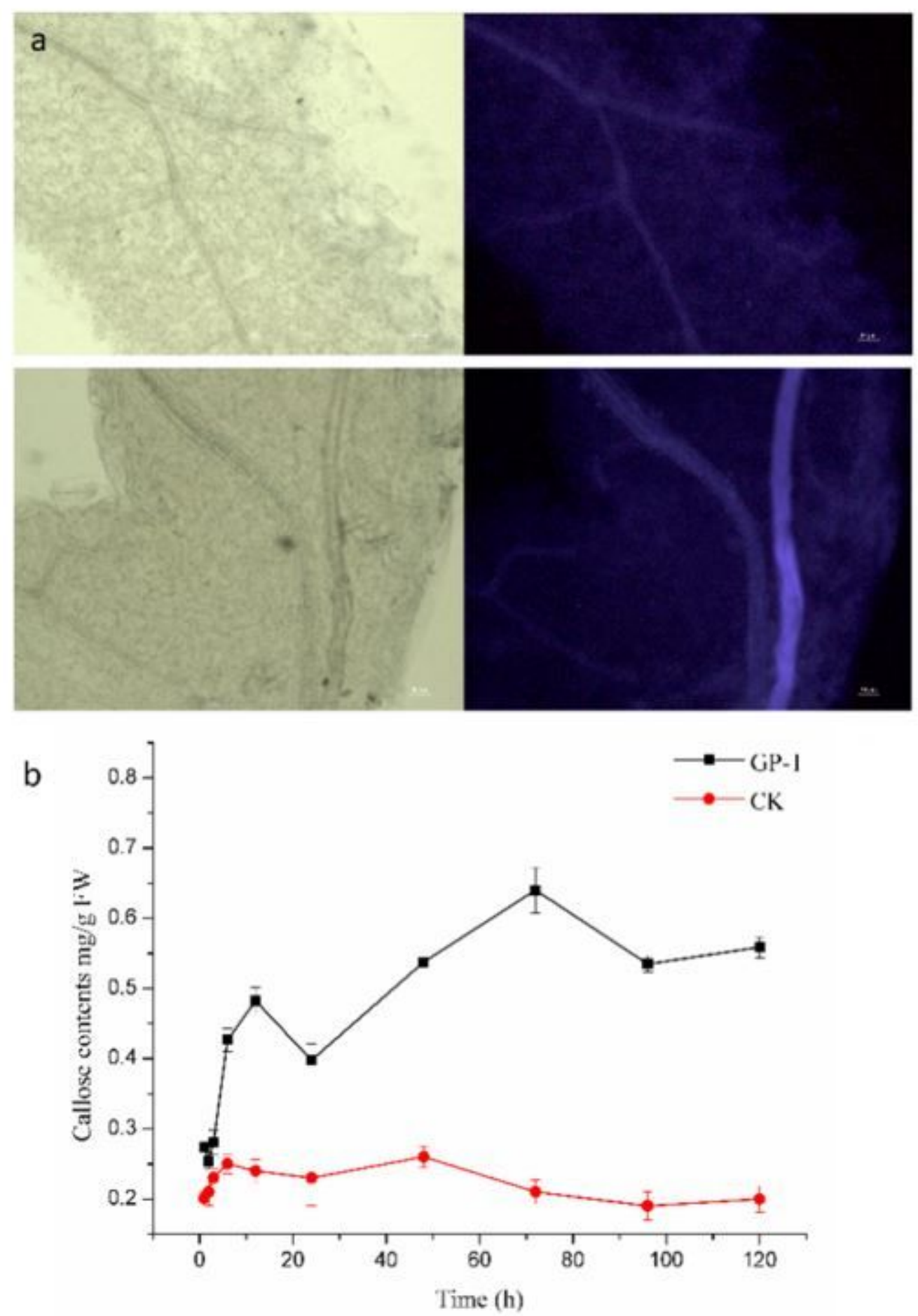

Figure 6

Callose production induced by GP-1. (a) Aniline blue staining of tobacco leaves with $50 \mu \mathrm{g} / \mathrm{mL}$ (top) or $100 \mu \mathrm{g} / \mathrm{mL}$ (bottom) GP-1 for $24 \mathrm{~h}$ observed under bright field (top and bottom left) or epifluorescence (top and bottom right) microscopy. (b) Quantification of callose induced by $100 \mu \mathrm{g} / \mathrm{mL} \mathrm{GP}-1$ for different times using aniline blue (excitation, $400 \mathrm{~nm}$; emission, $510 \mathrm{~nm}$ ). A calibration curve was established by using pachyman, and the callose content was expressed per mg of pachyman equivalents per $\mathrm{g}$ of leaf fresh weight (FW). 

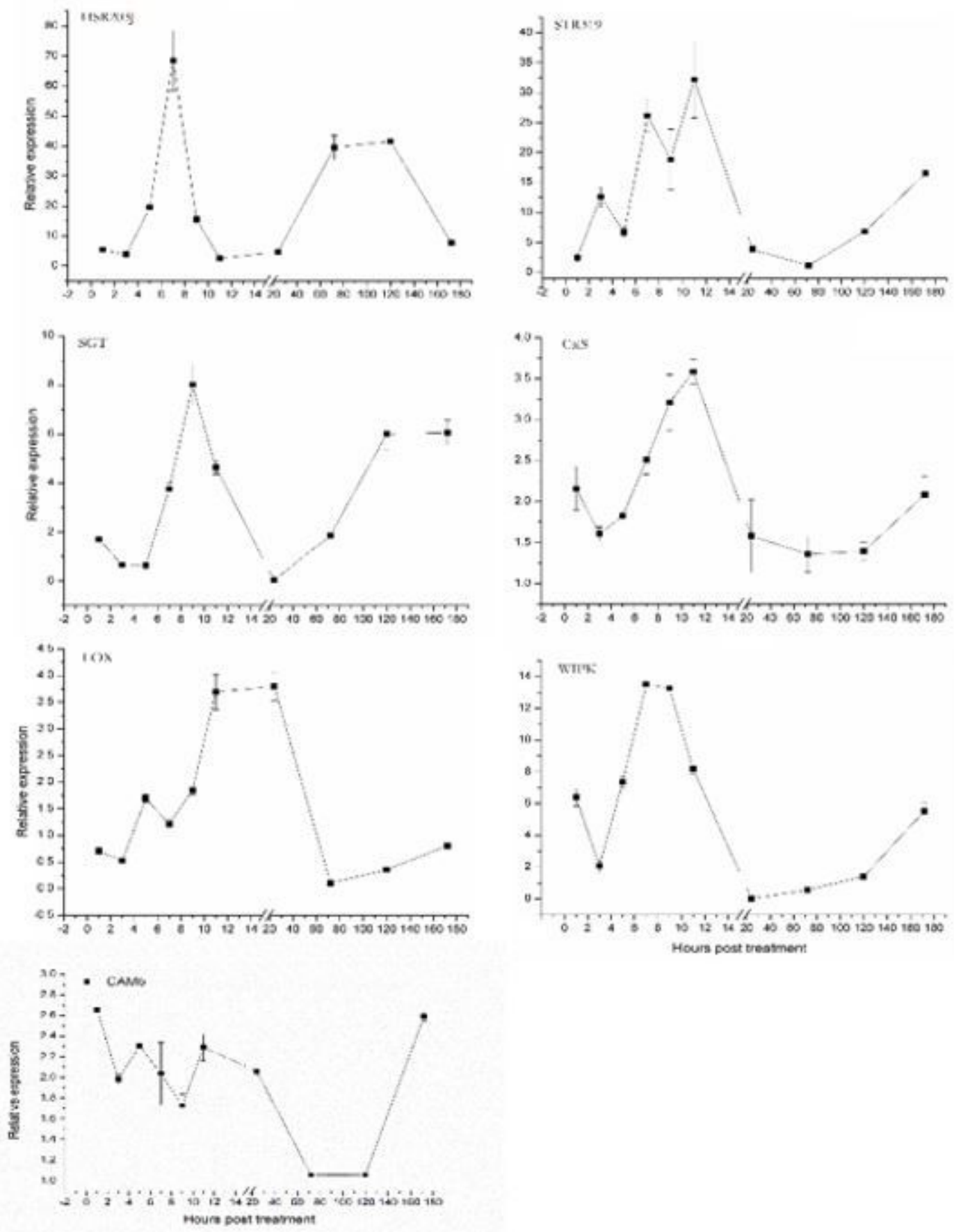

\section{Figure 7}

Relative expressions of tobacco defense-related genes after GP-1 treatment. The relative gene expression was quantified by using 2- $\Delta \Delta \mathrm{Ct}$ method (Livak, K.J. \& T.D. Schmittgen, 2001). At each time point, the relative expression of a gene from the treatment was compared against that from the control $(0 \mathrm{~d})$. Each assay included three technical and two biological replicates. The letters on the plots indicate significant difference according to Duncan's multiple range test at $p<0.01$ 

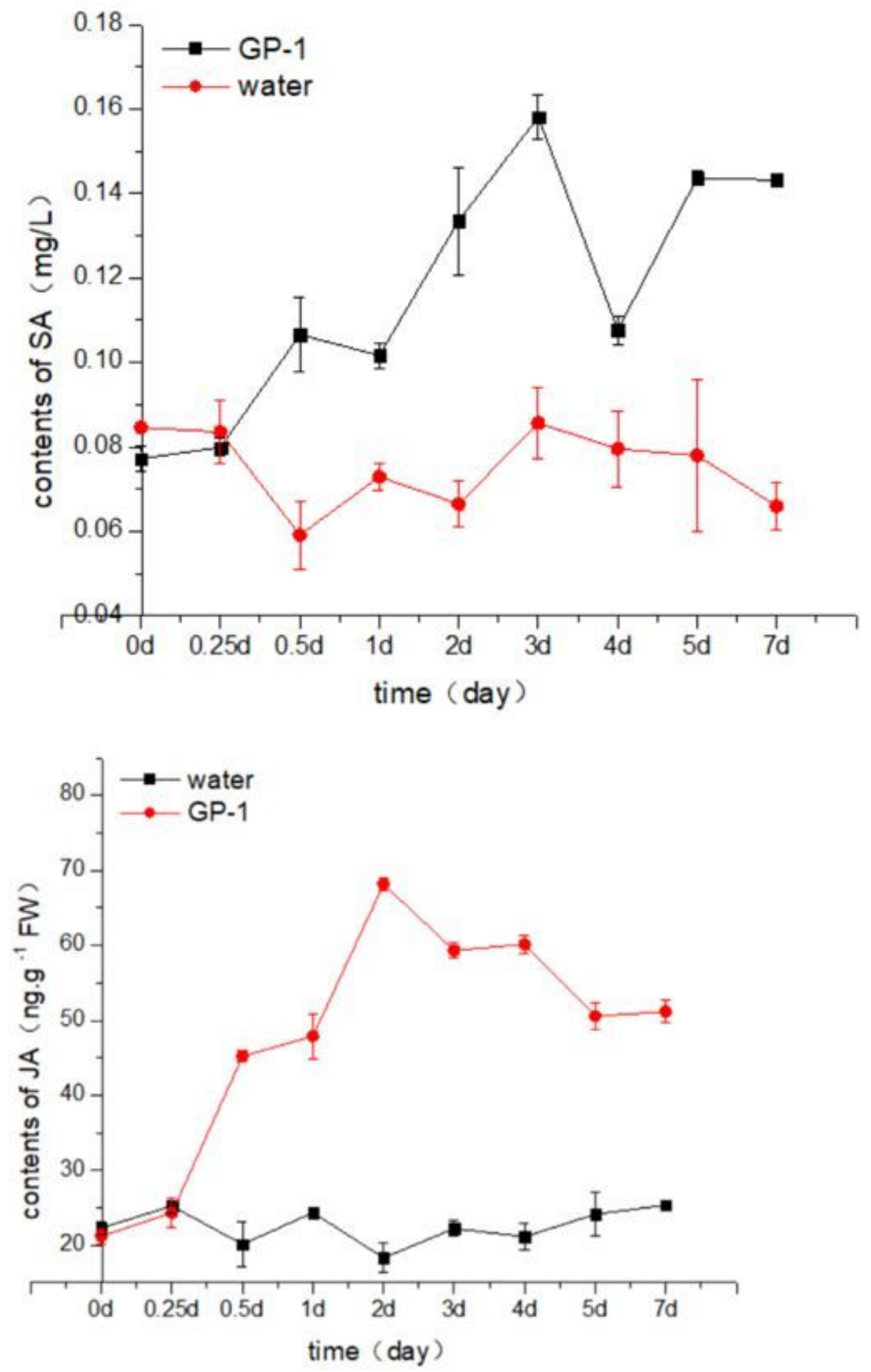

Figure 8

The contents of SA (a) and JA (b) in leaves of N. benthamiana after GP-1 treatment.

\section{Supplementary Files}

This is a list of supplementary files associated with this preprint. Click to download. 
- SupplementaryFigures.docx

Page 27/27 